\title{
LNG Transport and Management at South China Sea
}

\author{
$H \mathrm{Chen}^{1}, X C \mathrm{Cao}^{2, *}, C Y \mathrm{Zhou}^{3}, J \mathrm{Wang}^{4}, Y \mathrm{Qin}^{5}$ and $M \mathrm{Chen}^{6}$ \\ ${ }^{1}$ Sinopec Hainan Petroleum Branch, Haikou, HN 570100, China \\ ${ }^{2}$ School of Petroleum Engineering, Northeast Petroleum University,Daqing, HLJ 163318, China \\ ${ }^{3}$ School of Information Technology and Electrical Engineering,University of Queensland, Brisbane, QLD 4072, AU \\ ${ }^{4}$ Production Technology Institute of Daqing Oilfiled Co. Ltd., Heilongjiang Provincial Key Laboratory of Oil and Gas Reservoir \\ Stimulation, Daqing, HLJ 163453, China \\ ${ }^{5}$ Production Technology Institute of Daqing Oilfiled Co. Ltd.,Daqing, HLJ 163453,China \\ ${ }^{6}$ Engineering and Technical Departmengt of No.2 Oil Plant of Daqing Oilfield, Daqing, HLJ 163453, China
}

\begin{abstract}
As China's research on LNG maritime transport is still in its infancy, there are few papers in relevant areas. Based on the description of the oil and gas contained in the South China Sea and the geographical location of the oil, the paper compares the natural gas liquefaction with nature, compares the three modes of natural gas transportation, and describes the influencing factors of LNG marine transportation.Secondly, Hainan Province was used as a case of transportation terminal to conduct market analysis and economic evaluation. Finally, considering of the unique resource background and geographical location of the South China Sea, suggestions are made to use effective, clean and comparative cheap energy.
\end{abstract}

\section{Introduction}

LNG ship transportation is the mainstream in maritime natural gas transportation. China has currently established 14 LNG terminals in a number of coastal cities. LNG only accounts for $4 \%$ of total energy consumption in China, therefore, there is a huge gap between $8.8 \%$ in Asia and $24 \%$ in the world.

The International Organization of LNG Importing Countries (GIIGNL) studied the LNG accidents that occurred in various member states from 1965 to 2007. The statistical indicators are the probability of accidents, the amount of LNG leakage, fires, and explosions[1]. It is essential for us to study LNG transport and management.

\section{LNG maritime transport}

\subsection{Basic Concepts}

LNG is a liquefied natural gas. Its main component is methane, with a few ethane, propane, butane, and sulfurcontaining substances besides water, addition to other non-hydrocarbons.

LNG terminal is the berth destination of LNG ships. After arriving at the destination, the LNG on board is transferred to other transportation equipment. Figure 1 shows aerial view of LNG terminal in Hainan, China.

LNG vaporization is the process of converting $\mathrm{LNG}$ to gaseous state by absorbing heat. The mainstream methods of vaporization include water bath and airtemperature heat exchange in China. Air-temperature heat exchange uses the natural heat in the air for heat exchange. In order to increase surface area of heat exchange.

LNG has following physicochemical properties:

- Low temperature. It forms liquid after cooling under normal pressure, and the liquefied temperature is $162.2^{\circ} \mathrm{C}$.

- $\quad$ Easily vaporized. LNG vaporization volume can expand 625 times compared to original status. Vaporized LNG shows a white mist in the air. Due to its low temperature nature, the surrounding water vapor is forced to condense.

- $\quad$ Non-toxic, odorless, colorless, easily soluble in oil and hardly soluble in water.

- Flammable. The upper and lower limits of the explosion are $5.5 \%$ and $14 \%$, respectively.

- Chemical stability.

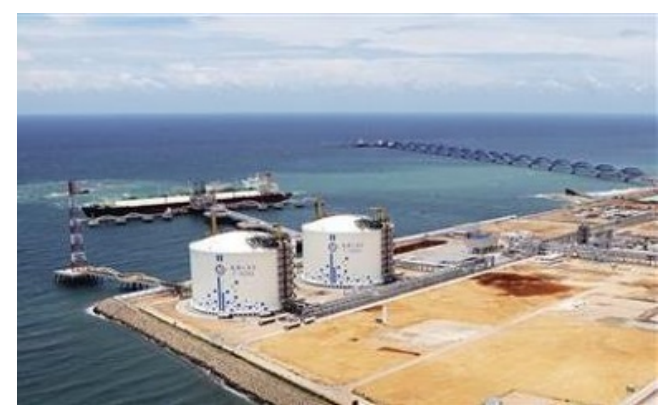

Fig 1. Aerial view of LNG terminal in Hainan. 


\subsection{LNG ships}

LNG ships currently carry cargoes ranging from 120,000 $\mathrm{m}^{3}$ to $150,000 \mathrm{~m}^{3}, 160,000 \mathrm{~m}^{3}$, and $200,000 \mathrm{~m}^{3}$. Some advanced countries own larger capacity LNG ships. Although at technical level, we have the ability to design larger capacity LNG ship, current cargo capacity has been remaining hundred thousand cubic meters due to various restrictions such as port terminal and receiving stations.

There are currently three main types of LNG cargo ships in circulation, which are film type, ball type and self-sustaining prism type. But the most common ones are thin-film and spherical [2]:

- The spherical cargo ship. A patented technology independently used by the Norwegian Moss Rosenberg shipyard, and the first spherical ship was designed in 1954. It has been adopted by the United States, Finland, and Japan. In the mid-1990s, South Korea invested heavily in patents for this technology and started to construct this kind of ship. The high-strength aluminum alloy ball warehouse is divided into three parts, namely the southern, northern hemisphere and the equator.

- Film-type cargo tank ship. The construction technology of this type of ship is becoming more and more perfect. It is smaller than the ball type, and the construction fee is lower than that of the ball type cargo ship.

- Self-sustaining prismatic cargo ship. The biggest difference of this ship to the other two cargo ships mentioned above is an additional longitudinal warehouse wall inside the cargo warehouse. The purpose is to divide the cargo warehouse into two, but the most fundamental reason is to reduce the random sway of the cargo in the cabin as much as possible, and to improve the stability of the ship to a certain extent. The warehouse is constructed with low temperature resistant aluminum alloy, and there is also a layer of plastic foam on the outside of the aluminum alloy for thermal insulation.

\subsection{The major LNG maritime transport}

Energy plays a pivotal role in economic development. Due to environmental problems, people began to look for clean energy. Because of oversupply of onshore natural gas reserves and the natural gas trade between countries, LNG maritime transportation emerged.

LNG transportation not only plays an important role in LNG industrial chain, but also connects upstream and downstream. LNG maritime transportation includes three links. They are liquefaction loading, maritime transportation, and unloading and vaporization.

\section{LNG maritime transport process and case analysis}

\subsection{LNG Transport Process}

LNG industry is not an independent industry, but has a corresponding industry chain, which requires huge capital and advanced science and technology to support. As we mentioned above, the entire process of the LNG industrial chain includes three parts, among which the third part is the LNG vaporization and sales. These three links are closely linked and have an inseparable relationship. All these three links are very important. As long as one of the links has a problem, the entire industrial chain will be affected, therefore, we must ensure that each link in the transportation process is in Good operating condition.

\subsection{Case analysis}

In this project, we mainly supplies gas to residents, industry and power generation users in Hainan, located in southern China. We comprehensively realize a complete energy structure and diversified energy supply to ensure the economy and safety of energy supply. According to the analysis of gas consumption in cities and counties of Hainan Province, the natural gas market demand for this project in 2020, will be reached $14.92 \times 10^{8} \mathrm{~m}^{3} / \mathrm{a}$ and the natural gas market in major provinces in the province will be reached $49.90 \times 10^{8} \mathrm{~m}^{3} / \mathrm{a}$ in 2020.

Annual operating cost of an LNG ship refers to the total expenditure of the ship within one year, also known as the annual shipping cost of a single ship. The current operating cost estimation formula is divided into five major items. The total annual cost is these five items:

- $\quad$ ship-related costs.

- crew costs.

- fuel costs.

- port charges.

- other costs

\section{Expenses and costs}

\subsection{Expenses}

Ship prices related to ship prices include depreciation, repair and insurance costs. After the ship starts to be used, its value decreases year by year. The annual fee drawn by the shipping company based on the depreciation rate during the service life is the depreciation rate. At present, the most commonly used depreciation method in the world is the straight-line depreciation method, the formula is:

$$
D=\frac{P-L}{N}
$$

Where, $D$ stands for depreciation fee, $P$ stands for ship price, $L$ stands for residual value and $N$ stands for service life span.

In order to maintain the normal operation of vessels and ships to meet our needs, we must carry out an annual inspection (once a year), intermediate surveys (once 
every two and a half years) and special survey (every five years).

Cost information indicates that the current cost of a normal LNG ship with a capacity of $170,000 \mathrm{~m}^{3}$ is about $\$ 200$ million [3]. The service life span of LNG ships is usually 40 to 50 years. In our calculation, 45 years is used, and the retained value is $10 \%$ of the standard value. The average annual depreciation price of this type of LNG ship is \$ 4.5 million. According to China's standard, in the period of marine regular industrial insurance, total loss insurance (including piracy insurance), the insurance cost of the LNG ship is $0.45 \% \times 12$ cost of the ship, that means that this insurance fee is $\$ 1.08$ million. The repair cost of the ship is generally $3 \%$ of the ship price, therefore it is $\$ 6$ million.

\subsection{Crew costs}

According to international industry standards, the salaries of LNG ship staff are higher than those of ordinary ship transport staff. According to the standard of 22 staff for large ships, the annual salary of the personnel is about $\$ 653,212$. The specific cost structure is shown in Table 1.

Table 1. Large LNG ship staff vs salaries (unit: USD).

\begin{tabular}{|c|c|c|c|c|}
\hline Serial & $\begin{array}{c}\text { Positio } \\
\text { ns }\end{array}$ & $\begin{array}{l}\text { Numb } \\
\text { er of } \\
\text { staff }\end{array}$ & $\begin{array}{c}\text { Month } \\
\text { ly }\end{array}$ & Salary \\
\hline 1 & Captain & 1 & 8,261 & 99,130 \\
\hline 2 & Mate & 1 & 6,696 & 80,348 \\
\hline 3 & Two & 1 & 3,478 & 41,739 \\
\hline 4 & Three & 1 & 2,174 & 26,087 \\
\hline 5 & $\begin{array}{c}\text { Chief } \\
\text { enginee } \\
\text { r }\end{array}$ & 1 & 7,826 & 93,913 \\
\hline 6 & $\begin{array}{c}\text { Large } \\
\text { tube } \\
\text { wheels }\end{array}$ & 1 & 6,696 & 80,348 \\
\hline 7 & $\begin{array}{l}\text { Second } \\
\text { tube } \\
\text { wheels }\end{array}$ & 1 & 3,478 & 41,739 \\
\hline 8 & $\begin{array}{c}\text { Electric } \\
\text { ians }\end{array}$ & 1 & 3,478 & 41,739 \\
\hline 9 & $\begin{array}{c}\text { Three } \\
\text { tube } \\
\text { wheels }\end{array}$ & 1 & 2,174 & 26,087 \\
\hline 10 & $\begin{array}{l}\text { Sailor } \\
\text { length }\end{array}$ & 1 & 1,565 & 18,783 \\
\hline 11 & $\begin{array}{l}\text { Mecha } \\
\text { nic }\end{array}$ & 1 & 1,565 & 18,783 \\
\hline 12 & Sailor & 5 & 1,478 & 17,739 \\
\hline 13 & $\begin{array}{c}\text { Mecha } \\
\text { nic }\end{array}$ & 3 & 1,478 & 17,739 \\
\hline 14 & $\begin{array}{l}\text { Electric } \\
\text { ian }\end{array}$ & 1 & 1,478 & 17,739 \\
\hline 15 & Chef & 1 & 1,478 & 17,739 \\
\hline 16 & Crew & 1 & 1,130 & 13,565 \\
\hline Total & & 22 & 54,435 & 653,212 \\
\hline
\end{tabular}

\subsection{Fuel costs}

Based on standard of a $174,000 \mathrm{~m}^{3} \mathrm{LNG}$ carrier, in the case of full load, where fuel consumption is approximately 140 tons / d when the ship is sailing at the speed of 19.5 knots. Hainan Yangpu LNG terminal has a limited speed of $8 \sim 12 \mathrm{~m} / \mathrm{s}$, we choose the median speed of $10 \mathrm{~m} / \mathrm{s}$, which means that the ship's speed is 19.5 knots, and the fuel consumption is about 140 tons/d. According to the above data, fuel consumption is 289 tons under one-way route. During the return trip, the cabin should be filled with water and ballast. The draught should be slightly lower than that of full-load navigation. According to experience, the fuel consumption is calculated at $80 \%$ of full-load, which is 231.2 tons. The current price of light-quality diesel in China is about $\$ 888$ (6,000 yuan RMB) per ton. Under full load conditions, the fuel cost of the one-way route is $\$ 256,600$

\subsection{Port fees}

Port fees are composed of various costs incurred by ships entering and leaving the port and in the port. The items involved in the port fee are basically the sum of the ship and the cargo, which is $2 \%$ of the ship price.

\subsection{Other costs}

Other costs should be $2 \%$ of the ship price.

\section{Simulation analysis}

Taking an example of a $174,000 \mathrm{~m}^{3}$ LNG ship, which carries LNG from the South China Sea to Yangpu Port in Hainan, the economic analysis of ship transportation on this route was carried out. The sailing distance from the South China Sea to Hainan Yangpu Port is about 1,789.2 $\mathrm{km}$. Assuming a sailing speed of 19.5 knots (that is, 10 $\mathrm{m} / \mathrm{s}$ ), one voyage takes approximately 49.5 hours, an annual operation of 310 days, and an annual number of voyages of 150 . Calculate the total annual operating cost and unit transportation cost of this type of ship (showed in Table 2).

Table 2. Economic simulation analysis.

\begin{tabular}{cc}
\hline Item & Amount (Unit: $\$ 10,000)$ \\
\hline Costs related to ship & 1158 \\
prices & 65.32 \\
Crew costs & $3,464.1$ \\
Fuel costs & 400 \\
Port costs & 400 \\
Other costs & $5,487.82$ \\
Yearly transportation & \\
costs & $\$ 0.0026 /(\mathrm{t} . \mathrm{km})$ \\
\hline
\end{tabular}

LNG shipping reduces transportation costs. According to the calculation results of the above transportation terminal, it can be obtained that the 
expenditure for transporting with large LNG ships is 0.017 yuan / $(\mathrm{t} \cdot \mathrm{km})$, which is not only lower than the highway freight, 0.6 yuan $/(\mathrm{t} \cdot \mathrm{km})$, but also lower than that of the railway freight, 0.3 yuan. / $(\mathrm{t} \cdot \mathrm{km})[3-5]$.

Transportation cost is, of course, related to the type of ship. The larger the LNG ship, the lower the transportation costs. Therefore, the transportation cost of using large LNG vessels is lower when allowed by port berthing conditions.

\section{Acknowledgments}

Authors wish to acknowledge assistance of all students and encouragement from all colleagues of Sinopec Hainan Petroleum Branch and School of Petroleum Engineering at Northeast Petroleum University.

\section{References}

1. Bian H Y. J 2019 J. Labour Protection vol 1 (Chinese) p 84

2. Barnes P, Oloruntoba R. J 2005 J. of International Management vol 11 p 519-540

3. Yang Q S, Zhao L L, Dai G L. J 2017 J. Price Theory and Practice vol 4 (Chinese) p 140

4. Li H, Huang H B. J 2010 J. Natural Gas Industry vol 1 (Chinese) p 86

5. Adhitya A, Srinivasan R and Karami I A. J $2009 \mathrm{~J}$. Process Systems Engineering vol 55 no 6 p 1447 1463 